\title{
Inflammatory and oxidative stress after surgery for the small area corrections of burn sequelae ${ }^{1}$
}

\author{
Estresse inflamatório e oxidativo após cirurgia para correção de \\ pequenas áreas de sequela de queimaduras
}

\author{
Paula Pileggi Vinha', Alceu Afonso Jordão JrII, Jayme Adriano Farina JrIII, Helio Vannucchi ${ }^{\mathrm{IV}}$, Júlio Sérgio Marchini ${ }^{\mathrm{IV}}$, Selma \\ Freire de Carvalho da Cunhav
}

\begin{abstract}
${ }^{1}$ Research performed at Division of Nutrology, Department of Internal Medicine, University Hospital, School of Medicine of Ribeirao Preto (FMRP), Sao Paulo University (USP), Ribeirao Preto-SP, Brazil. Part of the dissertation of the first author in Postgraduate Program in Internal Medicine, FMRP-USP. Tutor: Selma Freire de Carvalho Cunha.

${ }^{\mathrm{I}}$ Fellow PhD degree, Internal Medicine, FMRP-USP, Ribeirao Preto-SP, Brazil. Study concept and design, acquisition of data, analysis and interpretation of data, manuscript writing.

II Assistant Professor, Nutrition and Metabolism Course, Department of Internal Medicine, FMRP-USP, Ribeirao Preto-SP, Brazil. Technical procedures, interpretation of data, critical revision of the manuscript.

III Assistant Professor, Division of Plastic Surgery, Department of Surgery and Anatomy, FMRP-USP, Ribeirao Preto-SP, Brazil. Surgical procedures, manuscript writing.

IV Full Professor, Division of Nutrology, Department of Internal Medicine, FMRP-USP, Ribeirao Preto-SP, Brazil. Analysis and interpretation of data, critical revision of the manuscript.

${ }^{v}$ Assistant Professor, Nutrition and Metabolism Course and Division of Nutrology, Department of Internal Medicine, FMRP-USP, Ribeirao Preto-SP, Brazil. Tutor. Scientific and intellectual content of the study, statistic analysis, interpretation of data, critical revision, manuscript writing.
\end{abstract}

\begin{abstract}
Purpose: To compare vitamin levels, inflammatory and oxidative stress markers before and after skin autograft surgery to correct burn scar areas. Methods: This prospective study was conducted with 8 patients with a median age of 28 years (range, 16 to 40 years) that had burn sequelae and were admitted to a Burn Unit for correction of small burn scar areas [3.3 (1.0-5.0) \% of the corporal surface]. The volunteers were evaluated before and 48 hours after excision of scar tissue and skin autograft. Routine laboratory data, along with a food questionnaire and anthropometry were collected in the preoperative period. Serum vitamin A, C, E, B 12 and folic acid levels, inflammatory markers (C-protein reactive, alpha-1-acid glycoprotein, ferritin) and oxidative stress markers (reduced glutathione - GSH and Thiobarbituric Acid Reactive Substances - TBARS) were determined at preoperative and postoperative phases. Data were analyzed with two-sample Wilcoxon test. Results: All volunteers were clinically stable and had adequate nutritional status at admission. After surgery, C-reactive protein serum levels increased [0.4 (0.01-1.0) vs. $2.5(0.6-4.7) \mathrm{mg} / \mathrm{dL}, \mathrm{p}=0.01]$ and vitamin A levels decreased [3.4 (2.1-4.2) vs. 2.4 (1.6-4.1) $\mu \mathrm{mol} / \mathrm{L}, \mathrm{p}=0.01]$. No changes occurred in other vitamins, ferrritin, alpha-1-acid glycoprotein, GSH and TBARS levels. Conclusion: Minimal metabolic changes were produced after skin autograft in small areas of well-nourished patients without active infection or inflammation.
\end{abstract}

Key words: Oxidative Stress. Nutritional Status. Burns. Surgical Procedures, Operative.

\section{RESUMO}

Objetivo: Comparar os níveis séricos de vitaminas e dos marcadores de estresse oxidativo e inflamatório antes e após enxerto cutâneo para correção de pequenas áreas de cicatrizes hipertróficas de queimaduras. Métodos: O estudo prospectivo foi conduzido com oito pacientes com mediana de idade de 28 anos (variação de 16 a 40 anos) que apresentavam cicatrizes fibróticas decorrentes de queimaduras. Todos os pacientes foram admitidos em Unidade de Queimados para serem submetidos a enxertos autólogos [3,3 (1,0 a 5,0)\% da superfície corporal]. Os voluntários foram avaliados antes e 48 horas após a excisão do tecido cicatricial e do enxerto autólogo. Exames laboratoriais de rotina, além do questionário alimentar e da antropometria foram obtidos no período pré-operatório. Os níveis séricos das vitaminas $\mathrm{A}, \mathrm{C}, \mathrm{E}, \mathrm{B}_{12}$ e ácido fólico, os marcadores inflamatórios (proteína C reativa, alfa-1-glicoproteína ácida 
e ferritina) e marcadores de estresse oxidativo (glutationa reduzida - GSH e Substâncias Reativas do Ácido Tiobarbitúrico - TBARS) foram determinados nas fases pré e pós-operatórias. Os dados foram analisados pelo teste de Wilcoxon pareado. Resultados: Todos os voluntários estavam clinicamente estáveis e apresentavam estado nutricional adequado à admissão hospitalar. Após a cirurgia, houve aumento dos níveis séricos de proteína $C$ reativa $[0,4(0,01-1,0)$ vs $2,5(0,6-4,7) \mathrm{mg} / \mathrm{dL}, \mathrm{p}=0,01]$, enquanto houve redução nos níveis de vitamina $\mathrm{A}[3,4(2,1-4,2)$ vs $2,4(1,6-4,1) \mu \mathrm{mol} / \mathrm{L}, \mathrm{p}=0,01]$. Não houve mudanças nos níveis séricos de outras vitaminas, ferritina, alfa1-glicoproteína ácida, GSH e TBARS. Conclusão: Em pacientes com bom estado nutricional e sem evidência de atividade inflamatória ou infecciosa ocorrem mudanças metabólicas mínimas após enxerto autólogo de pequenas áreas de cicatrizes de queimadura.

Descritores: Estresse Oxidativo. Estado Nutricional. Queimaduras. Procedimentos Cirúrgicos Operatórios.

\section{Introduction}

The rate of survival after thermal injury has improved in the past two decades ${ }^{1}$ but a large number of patients develop postburn scar contractures ${ }^{2}$. To restore anatomy and function, these patients require multistage correction surgery ${ }^{3}$ that includes single scar release, use of skin grafts, skin expansion, regional or free musculocutaneous or fasciocutaneous flaps.

Although free radicals influence the bactericidal capacity of neutrophils and macrophages, they are likely to cause structural, functional and biochemical cellular changes, as well as modification of membrane permeability, mitochondrial dysfunction, and cell damage and death ${ }^{4}$. The antioxidant substances, which include enzymes such as superoxide dismutase (SOD) and catalase, and non-enzymatic antioxidants such as the carotenoids, ascorbate, vitamin $\mathrm{E}$ and reduced glutathione $(\mathrm{GSH})^{5}$, are important to maintain low levels of free radicals. The antioxidants substances are critical to the organism survival and allow ischemic skin to recover from ischemia induced injury ${ }^{6}$.

Recent attention has been focused on the hypothesis that the accumulation of free radicals initiates a significant inflammatory response which includes the secretion of proinflammatory and anti-inflammatory cytokines that contribute to cellular injury ${ }^{7}$. The inflammatory response may cause changes in vascular permeability, alteration in the coagulation system, impairment of gut function, hypermetabolic response, and immune depression ${ }^{8}$, anorexia, weight loss and tissue waste 9 .

Although the intensity of oxidative stress is known to interfere with the clinical course of victims of acute thermal trauma ${ }^{10}$, this aspect has not been evaluated after surgical reconstruction of postburn contractures. In animal models of skin ischemia, the intensity of local inflammatory response and an imbalance in the formation of free radical and antioxidant substances may be important in the clinical evolution as well as the survival of skin flaps ${ }^{6}$. It was hypothesized that small areas of skin autograft cause metabolic changes including the elevation of inflammatory and oxidative stress markers. Thus, the purpose of this study was to compare vitamin levels, inflammatory and oxidative stress markers before and after skin autograft for the correction of small burn scar areas.

\section{Methods}

This prospective study was conducted in 2007 and 2008 at the Burn Unit of a Brazilian University Hospital. Eight volunteers with a median age of 28 years (range, 16 to 40 years), being 4 males and 4 females, were submitted to correction of burn scar contractures. In order to eliminate the interference of inflammatory stress caused by the acute burn, only subjects whose thermal trauma had occurred at least one year before the study [2 (121) years] were included. Volunteers with diabetes, cardiovascular disease, hepatic insufficiency, chronic renal insufficiency, and use of systemic corticosteroids were excluded.

This study was approved by the Institutional Ethics Committee. Written informed consent was obtained from each subject and all patients received treatment according to the preexisting protocol. The surgery lasted about 60 minutes and the same plastic surgery and anaesthetic team were involved in all procedures. The exeresis of scar tissue was performed, followed by a skin autograft using healthy skin from the patient himself. A thin slice of skin (0.005-0.010 in) was removed from the donor region, whose dimensions vary according to the area to be repaired (Table 1), using a Padgett ${ }^{\circledR}$ electric dermatome (Integra Lifesciences Corporate) or an Aesculap ${ }^{\circledR}$ dermatome (B. Braun Melsungen AG Division). If necessary, the graft was submitted to an expansion process with the aid of an external skin expander (Brenner Medical, Inc.) in order to cover a greater extension of the injured area. The extent of the surgically injured area was determined by the rule of Lund and Browder immediately after the reparative surgical procedure, considering the sum of the skin surface obtained by the exeresis of the scar injury and of the skin donor area. 
The Semi-quantitative Food Consumption Frequency Questionnaire was applied during the preoperative period in order to obtain information about food intake over the previous 6 months. Body weight and height were measured and the body mass index (BMI, $\mathrm{kg} / \mathrm{m}^{2}$ ) was calculated. Inflammatory stress markers (C-reactive protein, ferritin, acid $\alpha 1$-glicoprotein), serum vitamins (A, C, E, B 12 and folic acid) and oxidative stress markers (GSH and Thiobarbituric Acid Reactive Species - TBARS) were evaluated on two distinct occasions, i.e., preoperatively (Preoperative Phase) and 48 hours after surgical exeresis of the lesions and skin autograft applying (Postoperative Phase).

Serum C-reactive protein and acid $\alpha 1$-glycoprotein levels were determined by turbidimetry using commercial Cobas ${ }^{\circledR}$ kits, and ferritin levels were determined by chemoluminescence. Serum levels of vitamins A and E were determined by HPLC (Shimadzu, model LC10A). Vitamin C was determined by colorimetry and the analysis of folic acid and vitamin $B_{12}$ were performed on IMMULITE $^{\circledR}$. GSH was determined by the modified method of Sedlack and Lindsay ${ }^{11}$ and TBARS levels were determined by Buege and Austi's method ${ }^{12}$.

Data analyses were performed with Statistica software (version 7.0, StatSoft Inc.). Variables were analyzed by twosample Wilcoxon test, and are reported as median and range. The significance level was set at $\mathrm{p}<0.05$ in all analyses.

\section{Results}

None patients were taking supplemental vitamins. The daily nutrient intake was above the recommended dietary allowances regarding intake of energy [5433.8 (2652.0-11913.3) kcal), protein [195.0 (94.9-428.8) g), mineral and vitamins, including vitamin A [2558.6 (684.0-4953.0) IU), C [375.8 (297.0919.7) mg], E [22.2 (11.6-75.2) mg], $\mathrm{B}_{12}[11.5(1.7-74.4) \mu \mathrm{g}]$ and folic acid [684.7 (263.0-1224.7) $\mu \mathrm{g})$. During the preoperative period, the patients had normal range BMI values [23.4 (18.1$27.2) \mathrm{kg} / \mathrm{m}^{2}$ ]. Serum levels of clinical and nutritional biochemical indices before the surgical procedures were normal.

The surgical procedures were not complicated. There were no adverse effects related to the exeresis of scar tissue and skin autograft and none of the patients developed contracture recurrence. Table 1 describes the volunteers' demographic data, donor sites and deployed areas. The median total body surface area excised was $3.3 \%$ (range, $1.0-5.0 \%$ ).
TABLE 1 - Demographic data, donor sites and deployed areas of postburn contractures patients.

\begin{tabular}{cccccc}
\hline Patients & Gender $\begin{array}{c}\text { Age } \\
\text { (years) }\end{array}$ & Site scars & Donor site & $\begin{array}{c}\text { Injured area } \\
(\% \text { body } \\
\text { surface })\end{array}$ \\
\hline 1 & M & 29 & Arm & Scalp & 2.5 \\
2 & F & 40 & Axilla & Scalp & 5.0 \\
3 & F & 40 & Axilla & Scalp & 2.0 \\
4 & M & 31 & Dorsum of foot & Forearm and thigh & 2.5 \\
5 & M & 27 & Ear & Forearm & 1.0 \\
6 & F & 23 & Groin region & Thighs & 5.0 \\
7 & M & 27 & Anterior cervical region & Scalp & 4.0 \\
8 & F & 16 & Anterior cervical region & Arm & 4.0 \\
\hline
\end{tabular}

Surgical procedure caused an increase in C-reactive protein $(p=0.01)$ but no changes in other inflammatory stress markers levels were documented. Except for a reduction in serum vitamin A levels $(p=0.006)$, the serum levels of the other vitamins remained stable after the surgical procedure (Table 2). Reparative surgery did not cause any significant changes in serum GSH or TBARS concentrations.

TABLE 2 - Inflammatory and oxidative stress markers and vitamin levels before and after the surgical procedure.

\begin{tabular}{|c|c|c|c|c|}
\hline \multirow{2}{*}{ Measurements } & \multirow{2}{*}{ Units } & \multicolumn{2}{|c|}{ Phase } & \multirow{2}{*}{$\underset{\text { value }}{p}$} \\
\hline & & Preoperative & Postoperative & \\
\hline C-Reactive Protein* & $\mathrm{mg} / \mathrm{dL}$ & $0.4(0.01-1.0)$ & $2.5(0.6-4.7)$ & 0.01 \\
\hline Acid $\alpha 1$-glicoprotein & $\mathrm{mg} / \mathrm{dL}$ & $101.0(37.0-129.0)$ & $81.5(5.4-134.0)$ & 0.61 \\
\hline Ferritin & $\mathrm{ng} / \mathrm{mL}$ & $158.0(35.5-239.0)$ & $217.5(47.8-436.2)$ & 0.29 \\
\hline Vitamin A* & $\mu \mathrm{mol} / \mathrm{L}$ & $3.4(2.1-4.2)$ & $2.4(1.6-4.1)$ & 0.01 \\
\hline Vitamin C & $\mathrm{mg} / \mathrm{dL}$ & $0.9(0.5-1.3)$ & $0.8(0.6-1.3)$ & 1.0 \\
\hline Vitamin E & $\mu \mathrm{mol} / \mathrm{L}$ & $17.0(9.2-20.7)$ & $14.1(4.7-20.4)$ & 0.29 \\
\hline Vitamin $B_{12}$ & $\mathrm{pg} / \mathrm{mL}$ & $302.5(198.0-742.0)$ & $231.0(128.0-637.0)$ & 0.72 \\
\hline Folate & $\mathrm{ng} / \mathrm{mL}$ & $7.5(4.7-8.7)$ & $7.9(3.9-11.1)$ & 0.72 \\
\hline GSH & $\mu \mathrm{mol} / \mathrm{L}$ & $49.9(10.1-54.9)$ & $47.7(28.0-65.0)$ & 0.68 \\
\hline TBARS & $\mathrm{nmol} / \mathrm{L}$ & $1.3(1.1-4.3)$ & $1.4(0.01-8.7)$ & 1.00 \\
\hline
\end{tabular}




\section{Discussion}

The volunteers were in good nutritional condition before the surgical procedure, as shown by normal food intake, anthropometry and clinical laboratory data. Even considering the small scar contractures, the surgery caused an increase in C-reactive protein, which characterizes inflammatory stress. Except for a fall in serum vitamin A levels, the reparative surgery did not cause any changes in the other vitamin and markers of the anti- and pro-oxidant response.

Expressive increases in inflammatory and oxidative stress markers occur after various surgical modalities ${ }^{13,14}$. In the absence of complications related to the liposuction, there is a transitory increase in inflammatory activity, with no changes in oxidative stress markers ${ }^{15}$. However, oxidative stress was documented in follicular units during hair transplantation surgery, due to the effects of cold ischemia and reperfusion injury ${ }^{16}$.

The inflammatory stress observed after burn-excision procedures cannot be solely attributed to the general anaesthetic itself since the markers of inflammatory stress remained within normal limits in some patients ${ }^{17}$. Systemic endothelial dysfunction has been attributed to the inflammation or bacteraemia that occur after wound manipulation ${ }^{18}$ and greater blood loss at excision due to the relative hyperaemia ${ }^{19}$.

Depending on the intensity of inflammatory stress, there is a drastic and long-lasting reduction in vitamin A levels ${ }^{20}$, a phenomenon associated with the decrease in plasma transtirretin and retinol binding protein levels ${ }^{21,22}$. Thus, it is probable that the reduction in vitamin A levels observed in the present study was associated with a lower binding capacity of this vitamin.

The small sample size may have been a limitation of the present study but the homogeneous characterization of the participants and the consistent results obtained indicate that, albeit small, the number of patients evaluated was probably adequate. Furthermore, the time elapsed between surgery and blood collection (48 hours) may have been insufficient to detect possible changes in inflammatory stress markers. Because the injured area was small and relatively uniform, it was not possible to make the correlation between the extent of the surgically injured area and the markers of inflammatory or oxidative stress. However, it is possible that larger areas and multiple grafts or flaps cause most severe metabolic changes, similar to those observed following thermal trauma. Further studies are needed to assess the longitudinal evolution of more sensitive and specific inflammatory stress markers in order to be able to state that skin autografts of a small area trigger a few metabolic changes.

\section{Conclusion}

Minimal metabolic changes were produced after skin autograft in small areas of well-nourished patients without active infection or inflammation.

\section{References}

1. Barret JP, Herndon DN. Modulation of inflammatory and catabolic responses in severely burned children by early burn wound excision in the first $24 \mathrm{~h}$. Arch Surg. 2003;138:127-32.

2. Schneider JC, Holavanahalli R, Helm P, Goldstein R, Kowalske K. Contractures in burn injury: defining the problem. J Burn Care Res. 2006;27:508-14.

3. Figus A, Leon-Villapalos J, Philp B, Dziewulski P. Severe multiple extensive postburn contractures: a simultaneous approach with total scar tissue excision and resurfacing with dermal regeneration template. J Burn Care Res. 2007;28:913-7.

4. Waxman K. Shock: ischemia, reperfusion, and inflammation. New Horiz. 1996;4:153-60.

5. Soneja A, Drews M, Malinski T. Role of nitric oxide, nitroxidative and oxidative stress in wound healing. Pharmacol Rep. 2005;57 Suppl:108-19

6. Rees RS, Smith DJ Jr, Adamson B, Im M, Hinshaw D. Oxidant stress: the role of the glutathione redox cycle in skin preconditioning. Surg Res. 1995;58:395-400.

7. Greenhalgh DG, Saffle JR, Holmes JH 4th, Gamelli RL, Palmieri TL, Horton JW, Tompkins RG, Traber DL, Mozingo DW, Deitch EA, Goodwin CW, Herndon DN, Gallagher JJ, Sanford AP, Jeng JC, Ahrenholz DH, Neely AN, O'Mara MS, Wolf SE, Purdue GF, Garner WL, Yowler CJ, Latenser BA; American Burn Association Consensus Conference on Burn Sepsis and Infection Group. American Burn Association consensus conference to define sepsis and infection in burns. J Burn Care Res. 2007;28:776-90.

8. Beutler B, Cerami A. The common mediator of shock, cachexia, and tumor necrosis. Adv Immunol. 1988;42:213-31.

9. Yamada Y, Endo S, Inada K. Plasma cytokine levels in patients with severe injury with reference to the relationship between infection and prognosis. Burns. 1996;22:587-93.

10. Horton JW. Free radicals and lipid peroxidation mediated injury in burn trauma: the role of antioxidant therapy. Toxicology. 2003;189:75-88.

11. Sedlak J, Lindsay RH. Estimation of total, protein-bound, and nonprotein sulfhydryl groups in tissue with Ellman's reagent. Anal Biochem. 1968;25:192-205.

12. Buege JA, Aust SD. Microsomal lipid peroxidation. Methods Enzymol. 1978;52:302-10.

13. Polat C, Kahraman A, Yilmaz S, Koken T, Serteser M, Akbulut G, Arikan Y, Dilek ON, Gokce O. A comparison of the oxidative stress response and antioxidant capacity of open and laparoscopic hernia repairs. J Laparoendosc Adv Surg Tech A. 2003;13:167-73.

14. Urena R, Mendez F, Ruiz-Deya G, Baratta A, Thomas R, Sikka S. Does prolonged pneumoperitoneum affect oxidative stress compared with open surgical procedures? J Endourol. 2005;19:221-4.

15. Chang PY, Wu TL, Tsao KC, Sun CF, Lily L,Wu LL, Wu J T. Cosmetic liposuction causes only transient elevation of acute inflammatory response and does not advance to oxidative and nitrosative stress. J Clin Lab Anal. 2007;21:418-25.

16. Crisóstomo MR, Guimarães SB, de Vasconcelos PR, Crisóstomo MG, Benevides AN. Oxidative stress in follicular units during hair transplantation surgery. Aesthetic Plast Surg. 2011 Feb;35(1):19-23. 
Epub 2010 Jul 29.

17. Vlachou E, Gosling P, Moiemen NS. Microalbuminuria: a marker of systemic endothelial dysfunction during burn excision. Burns. 2008;34:241-6.

18. Papini RP, Wilson AP, Steer JA, Hill G, Mcgrouther DA, Parkhouse N. Plasma concentrations of tumour necrosis factor-alpha and interleukin-6 during burn wound surgery or dressing. Br J Plast Surg. 1997;50:354-61.

19. Janzekovic Z. The burn wound from the surgical point of view. J Trauma 1975;15:42-62.

20. Pintaudi AM, Tesoriere L, D'Arpa N, D'Amelio L, D'Arpa D, Bongiorno A, Masellis M, Livrea MA. Oxidative stress after moderate to extensive burning in humans. Free Radic Res. 2000;33:139-46.
21. Baeten JM, Richardson BA, Bankson DD, Wener MH, Kreiss JK, Lavreys L, Mandaliya K, Bwayo JJ, Mcclelland RS. Use of serum retinol-binding protein for prediction of vitamin A deficiency: effects of HIV-1 infection, protein malnutrition, and the acute phase response. Am J Clin Nutr. 2004;79:218-25.

22. Tanumihardjo SA. Assessing vitamin A status: past, present and future. J Nutr. 2004;134:290S-293S.

\section{Correspondence:}

Selma Freire de Carvalho da Cunha

Departamento de Clinica Médica

Faculdade de Medicina de Ribeirão Preto-USP

Av. Bandeirantes, 3900

14048-900 Ribeirão Preto - SP Brasil

Tel: (55 16)3602-3369

$\operatorname{Fax}(55$ 16)3633-6695

sfreire@fmrp.usp.br
Conflict of interest: none

Financial source: FAPESP

Received: December 10, 2010

Review: February 14, 2011

Accepted: March 15, 2011 